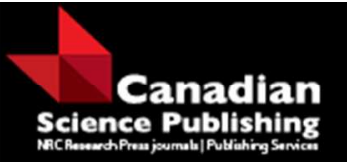

Canadian Journal of Forest Research

Revue canadienne de recherche forestière

\title{
Populus tremuloides stands continue to deteriorate after drought-incited sudden aspen decline
}

\begin{tabular}{|r|l|}
\hline Journal: & Canadian Journal of Forest Research \\
\hline Manuscript ID & cjfr-2015-0225.R1 \\
\hline Danuscript Type: & Article \\
\hline Complete List of Authors: & $\begin{array}{l}\text { Worrall, Jim; USDA Forest Service, Rocky Mountain Region } \\
\text { Keck, Andrew; Western State Colorado University, Department of } \\
\text { Mathematics and Computer Science } \\
\text { Marchetti, Suzanne; USDA Forest Service, Rocky Mountain Region }\end{array}$ \\
\hline Keyword: & decline disease, climate change, regeneration, recent crown loss, aspen \\
\hline \multicolumn{2}{|c}{} \\
\hline
\end{tabular}


1 Populus tremuloides stands continue to deteriorate after drought-incited sudden aspen decline

3 James J. Worrall

$4 \quad$ Forest Health Protection, Rocky Mountain Region, US Forest Service, 216 N. Colorado

$5 \quad$ St., Gunnison, CO, 81230, USA, jworrall@fs.fed.us

6 Andrew G. Keck

7 Department of Mathematics and Computer Science, Western State Colorado University, $8 \quad$ Gunnison, CO, 81231, USA

9 Suzanne B. Marchetti

11 St., Gunnison, CO, 81230, USA

13 Correspondence:

14 James J. Worrall, jworrall@fs.fed.us, voice: (970) 642-4453, fax: (970) 642-4425

15 US Forest Service, 216 N. Colorado St., Gunnison, CO, 81230, USA 
17 Abstract: Reports of forest damage have increased with the frequency of climatic extremes, but

18 longer-term impacts of such events on population dynamics of forest trees are generally

19 unknown. Incited by the turn-of-the-century drought, sudden aspen decline (SAD) damaged

20535,000 ha of Populus tremuloides in the Southern Rockies ecoregion of western North

21 America. Although spread of the disease stopped about 2009, most affected stands continued to

22 deteriorate. Remeasurement of plots in southwestern Colorado showed that, since the peak of

23 the epidemic, live basal area in sick plots decreased an additional $28 \%$ to only $38 \%$ of that in

24 healthy plots. Sick plots had much more recent damage than healthy plots: almost three times as

25 much recently dead basal area, over twice the density of recently dead trees, and almost four

26 times as much recent crown loss. The important contributing agents in SAD were still active in

27 sick stands in 2013. Density of small regeneration showed opposite trends, increasing in healthy

28 plots and decreasing in sick plots. Timely regeneration treatments may be needed in some such

29 stands to facilitate recovery. In addition to acute damage from climatic extremes, long-term

30 decline diseases like SAD will likely be a common signature of forest damage from climate

31 change.

32 Keywords: decline disease; climate change; regeneration; recent crown loss. 


\section{$34 \quad$ Introduction}

35 Partly as a result of recent climatic extremes, reports of tree mortality are increasing around the

36 world (Allen et al. 2010). These include subtle increases in rates of "background" mortality (van

37 Mantgem et al. 2009) as well as spectacular, large-scale episodes of mortality (Michaelian et al.

38 2011).

39 Climatic extremes impact tree species in complex ways, interacting with various other abiotic

40 and biotic factors. The concept of decline diseases is useful in understanding the processes

41 involved in large-scale mortality events because it helps to organize and attribute roles to the

42 various causal factors, highlighting the complexity rather than a simplified focus on a single

43 cause. Often, etiology is organized into predisposing, inciting, and contributing factors (Manion

44 1991; Manion and LaChance 1992). Predisposing factors are long-term, static or slowly

45 changing factors such as site and stand conditions or chronic damage from insects and

46 pathogens. Inciting factors are short-term abiotic or biotic agents that cause acute stress at a

47 point in time, such as climatic extremes or severe defoliation events. Trees affected by inciting

48 factors alone may recover quickly, but recovery is much slower if the damage is exacerbated by

49 predisposing factors. Finally, contributing factors, or proximate causes, kill trees that were

50 debilitated by predisposing and inciting factors. Contributing factors are typically a suite of

51 secondary insects and pathogens.

52 Sudden aspen decline (SAD) is a decline disease of trembling aspen (Populus tremuloides) that

53 is incited by severe, warm drought (Rehfeldt et al. 2009; Worrall et al. 2013). Predisposing

54 factors include site conditions that render stands vulnerable to drought damage, such as low

55 elevation, southern to western aspects, relatively flat slopes, and upper slope positions (i.e., 
56 summits vs. toeslopes) (Worrall et al. 2010). Contributing factors include a variety of

57 interchangeable, secondary insects and pathogens that kill stressed trees. Subsequent high

58 populations of these agents may allow them to kill relatively healthy trees (Marchetti et al.

59 2011). Symptoms of SAD are rapid, synchronous branch dieback, crown thinning, and mortality

60 of overstory trees on a landscape scale, without the involvement of primary pathogens and

61 insects.

62 In 2002, a multi-year drought that stretched from western Mexico to the Canadian Prairies

63 reached its peak with the most severe drought conditions on record in many areas. Often called

64 the turn-of-the-century drought, by some measures it was the most severe in western North

65 America in over 800 years (Schwalm et al. 2012). In Colorado, SAD was first noticed in 2004

66 (Worrall et al. 2008). The largest area recorded by aerial survey was in 2008, and by 2010 it had

67 practically ceased to affect new areas. Over 2000-2010, SAD was recorded on about 535,000 ha

68 in the Southern Rockies ecoregion and 492,000 ha in Colorado. Similar, roughly

69 contemporaneous declines were noted in aspen across North America (Worrall et al. 2013).

70 In 2007-2008, affected stands in southwestern Colorado had an average 54\% recent crown loss

71 and $45 \%$ of the standing aspen stems were dead (Worrall et al. 2010). Compared to healthy

72 stands, the proportion of roots that were dead nearly tripled in affected stands, and regeneration

73 did not increase in response to overstory damage. This led to management concerns over the

74 future of aspen in affected landscapes.

75 There are many reasons to maintain aspen where possible. It is a keystone species in western

76 North America, important to diversity of wood-decay fungi (Gilbertson 1980), plants (Kuhn et

77 al. 2011; Mueggler 1985), birds (Flack 1976; Turchi et al. 1995), and mammals large and small 
78 (Oaten and Larsen 2008). Aspen modifies hydrological properties (LaMalfa and Ryel 2008) and

79 microclimate in ways that improve stream flow and foster luxuriant growth of varying herb and

80 shrub layers, providing forage for wildlife and livestock. Aspen wood is useful for paneling,

81 oriented strandboard, pulp, and excelsior. The scenic beauty of aspen is a major contributor to

82 the tourism economy in many areas.

83 To guide management responses to such an episode, we need to understand: (a) causal factors;

84 (b) impact of the episodes on subsequent population dynamics, and; (c) future climate trends and 85 their long-term impacts on the species' local climatic niche. Our focus in this paper is (b). Do

86 forests impacted by drought-incited declines recover naturally, or can such climatic extremes

87 initiate long-term deterioration? Such knowledge also can help us anticipate the impacts of

88 severe droughts that are expected to be more common in the future due to climate change.

89 However, since the peak of the epidemic, the subsequent fate of affected stands has been largely

90 unknown. While limited remeasurement of a small subset of plots a year or two after the first

91 measurement indicated continuing deterioration (Worrall et al. 2010), some observers have

92 suggested that affected stands have largely recovered and that the impact of the disease was

93 difficult to discern several years after the epidemic. Thus, our objectives were to compare

94 current overstory and regeneration conditions in healthy and damaged stands with conditions

95 immediately at the peak of the epidemic, and thereby infer trends in overstory mortality and

96 regeneration.

\section{$97 \quad$ Methods}

98 During the peak of the SAD epidemic in 2007/2008, 162 plots were established throughout much 99 of southwestern Colorado (Fig. 1) (Worrall et al. 2010). All plots were required to have live 
100 aspen basal area $\geq 2 \mathrm{~m}^{2} \mathrm{ha}^{-1}$ with aspen as the leading species in basal area. Half were in sick 101 aspen stands randomly selected from polygons identified as SAD in aerial survey; for plot 102 establishment they were required to have $>25 \%$ recent crown loss. Each was paired with a 103 randomly selected, neighboring, healthy ( $\leq 25 \%$ recent crown loss) aspen plot. Plot centers were 104 marked with wood stakes and GPS coordinates were recorded.

105 To remeasure plots in 2013, we navigated to the GPS coordinates. If we found the stake with the 106 tip still embedded in the soil, we used that point as plot center and the plot was noted as precisely 107 relocated. Otherwise, we used the plot center indicated by the GPS coordinates and noted the 108 plot as imprecisely relocated. Such plots were checked to see if they met the original criteria.

109 For the 11 plots that did not, systematic rules were followed to establish a replacement plot in the 110 immediate area without bias. All plot centers were marked with steel rods.

111 As before (Worrall et al. 2010), overstory trees ( $\geq 12 \mathrm{~cm} \mathrm{DBH)} \mathrm{were} \mathrm{sampled} \mathrm{with} \mathrm{a} \mathrm{variable-}$

112 radius plot, choosing a basal-area factor $\left(1,2\right.$, or $\left.3 \mathrm{~m}^{2} \mathrm{ha}^{-1}\right)$ to target 10-20 trees for sampling.

113 Recent crown loss (RCL) was estimated as the percent of foliage that was apparently lost, either

114 due to recent branch and twig dieback or crown thinning. Old dead branches without fine twigs

115 or with $<50 \%$ of bark intact were not considered part of the crown and were ignored. Dead

116 standing trees were considered recently dead (i.e., 100\% RCL) if they had any recently dead

117 branches; otherwise they were considered snags and not included in the average RCL.

118 Regeneration was sampled in 0.01-ha plots (radius $5.642 \mathrm{~m}$ ), and evidence of browsing of

119 regeneration was recorded. Regeneration was sampled in three size classes: small (30 to $137 \mathrm{~cm}$ 120 tall), medium (0.1 to $2.9 \mathrm{~cm} \mathrm{DBH})$, and large (3.0 to $11.9 \mathrm{~cm} \mathrm{DBH})$. Only small regeneration

121 responded to the factors studied here, so data on medium and large regeneration are not 
122 presented. Small aspen regeneration is referred to here as "suckers", although some may have 123 been seedlings.

124 Also as before, we recorded presence of damaging insects and pathogens on live and recently

125 dead aspen. These included aspen bark beetles (dominated by Trypophloeus populi, but

126 Procryphalus mucronatus could not be consistently distinguished in the field), bronze poplar

127 borer (Agrilus liragus), Cytospora canker (caused by several species, but usually attributed to

128 Valsa sordida), poplar borer (Saperda calcarata), white trunk rot (caused by Phellinus

129 tremulae), and sooty-bark canker (caused by Encoelia pruinosa).

130 Stable aspen stands are those that tend to regenerate to aspen over long periods of time, often in

131 the absence of disturbance, while seral stands undergo gradual succession to conifers (Rogers et

132 al. 2014). We used two criteria to classify stands as stable (P.C. Rogers, personal

133 communication, 2014): $<10 \%$ live basal area in conifers, and $<100$ conifer seedlings or saplings

$134(<12 \mathrm{~cm} \mathrm{DBH})$ per hectare.

\section{Statistical analysis}

136 Two sick plots were removed in the first analysis because they were outliers in various respects

137 (Worrall et al. 2010), and were removed this time also. One was frequently flooded, old, with a

138 nearly dead overstory (not related to SAD) and heavy regeneration. The other had severe insect

139 defoliation causing heavy crown loss and had no dead roots. In addition, a healthy plot that had

140 been harvested in the interim was removed because the study was not designed to study

141 harvesting as a factor. Although it barely met the criteria for sampling, regeneration was much

142 higher than any other plot as a result of the harvest $\left(58,400\right.$ stems ha $\left.^{-1}\right)$. 
143 To account for the pairing of two measurements, for each plot and variable we subtracted

144 2007/08 values from 2013 values. Thus, the variates we worked with were the change between

145 years. As the yearly measurements were consistent with log normal distributions, pairing them

146 produced normally distributed change variables.

147 Statistical procedures are described in Venables and Ripley (2002) and in the documentation of

148 R (R Core Team 2014), which was used to conduct the analyses. Each change variable was

149 analyzed by fitting a multiple linear regression model using plot type (healthy vs. sick), precise

150 relocation (yes or no), nine other covariates representing site and stand factors (elevation minus

151 mean elevation, stand structure [single-story, two-story, multi-story, and mosaic], slope, slope

152 position, aspect encoded by quadrant as north, east, south, or west, upland vs. riparian, conifer

153 relative basal area, stable vs. seral, and browse) as main effects, and terms representing the

154 interaction between plot type and the remaining covariates. This saturated model contained 21

155 parameters, most of which were not statistically significant. To remove the nonsignificant terms

156 a termwise deletion procedure was applied using the Akaike information criterion (AIC) to

157 remove the least significant term at each step to produce a reduced model. Any remaining

158 interaction terms were assessed termwise using nested ANOVA and removed if not statistically

159 significant $(\alpha=0.05)$. After the nonsignificant interaction terms were removed, each main term

160 not involved in a remaining interaction term was tested with an F-test and removed if not

161 significant to produce the final model for the change variable. The only variables significantly

162 influenced by precise relocation were live basal area (main effect, $\mathrm{p}<0.001$ ) and live density

163 (interaction with plot type, $\mathrm{p}=0.022$ ). Therefore, we analyzed these change variables using only

164 precisely relocated plots (77 of 159 plots). 
165 To compare healthy and sick plots within years (not using the difference variables), we used

166 Wilcoxon rank sum tests (= Mann-Whitney test). For frequencies of biotic agents and other tests

167 of frequencies, equality of proportions was tested using a chi-squared test for equal distribution.

\section{Results}

\section{Overstory}

170 Change between measurements. In healthy plots, overstories experienced little change. Most

171 variables did not change significantly (Figs. 2 and 3; density data are not shown as they largely

172 mirror basal area), including basal area of live trees $(\mathrm{p}=0.132, \mathrm{t}=1.522, \mathrm{df}=73$, multiple

173 regression on significant covariants), of recently dead trees $(p=0.53)$, and of snags $(p=0.09)$, and

174 recent crown loss $(\mathrm{p}=0.96)$. The only exceptions were an overall increase in density of snags

175 regardless of plot type (46 stems $\left.\mathrm{ha}^{-1} ; \mathrm{p}=0.002\right)$ and, after correcting for the effects of relative

176 basal area of conifers and seral status, an increase in density of recently dead trees (71 stems ha ${ }^{-1}$;

$177 \mathrm{p}=0.006)$.

178 Sick plots, on the other hand, experienced greater change. Some measures of current damage

179 decreased since the first measurement, at the peak of the SAD epidemic. These include basal

180 area of recently dead trees and recent crown loss (both $\mathrm{p}<0.001)$. However, other change

181 variables showed continuing losses. Density of recently dead trees decreased but the change was

182 marginally significant at the $95 \%$ level $(\mathrm{p}=0.052)$, live basal area decreased $28 \%(\mathrm{p}=0.008)$, and

183 snag basal area increased $(\mathrm{p}<0.001)$.

184 Although density of live trees decreased $25 \%$ in sick plots and $7 \%$ in healthy plots, the overall

185 change was explained by elevation and stand structure and was not significant after removing the 
186 effects of those variables $(\mathrm{t}=-0.724, \mathrm{p}=0.471)$. Change in live density was not influenced by plot 187 type $(\mathrm{F}=1.0154, \mathrm{p}=0.317)$.

188 Healthy vs. sick plots. In both measurements, sick plots had significantly less live density and 189 basal area than healthy plots (all $\mathrm{p}<0.001$ ). By 2013 the live basal area in sick plots dropped to 190 only $38 \%$ of that in healthy plots. Levels of recent damage in sick plots still far exceeded those 191 in healthy plots. In 2013, sick plots had significantly higher basal area of recently dead trees, 192 density of recently dead trees, and recent crown loss than healthy plots (all $\mathrm{p}<0.001)$.

193 Insects and biotic diseases. All biotic agents that were significantly more frequent in sick plots 194 than in healthy plots in 2007/08 (Marchetti et al. 2011) remained so in 2013 (Table 1). Between 195 the measurements there were significant increases or decreases of some agents, but the 196 magnitudes of these changes were small compared to the differences between plot types, 197 especially for the contributing agents. The most notable example of such change was bronze 198 poplar borer, which nearly doubled in healthy plots and decreased by a quarter in sick plots.

\section{Regeneration}

200 Density of aspen suckers increased in healthy plots, but decreased in sick plots. In linear models 201 with change of sucker density as a response variable, and various site and stand factors as 202 independent variables, only plot type was important $(\mathrm{p}=0.002)$. In healthy plots, suckers 203 increased significantly $(\mathrm{p}=0.014)$ with a mean increase of 670 stems ha $^{-1}$. In contrast, sick plots 204 lost an average of 500 stems $^{-1} \mathrm{a}^{-1}$ over the course of the study, although that change was not 205 significant in the stepwise analysis $(\mathrm{p}=0.066)$. Because the stepwise analysis determined that 206 only plot type was important, we investigated the change in sick plots further with the Wilcoxon 207 test, which indicated that the change in sick plots was significant $(\mathrm{p}=0.003)$. In 2013 , of 79 sick 
208 plots, 11 had no suckers $(14 \%$ of plots; $95 \%$ confidence interval $=7-24 \%)$. Thirty-six plots had $209 \leq 300$ stems ha $^{-1}(46 \%$ of plots, $95 \%$ confidence interval $=34-57 \%)$.

210 Density plots (Fig. 4) show a qualitative shift in sucker density among healthy plots. The plateau

211 that formed in 2013 at about 4500 stems ha $^{-1}$ suggests that a sizable subset of healthy plots

212 changed their mode, moving from near 0 stems $^{-1}$ to the range $3000-6000$. Further

213 examination showed that 13 healthy plots with $<2000$ stems ha $^{-1}$ in 2007/08 had >3000 in 2013.

214 These tended to be the healthiest of plots: compared to other healthy plots they had little or no

215 recent dead, snag density went down instead of up, recent crown loss decreased greatly, and live

216 basal area was high. Among sick plots, there was an opposite but less distinct shift to lower

217 sucker density, with the population becoming more concentrated near 0 stems ha ${ }^{-1}$.

\section{Site and stand factors}

219 Seral type (stable or seral) had no influence on SAD occurrence. Using a criterion of $<10 \%$

220 basal area in conifers, $70 \%$ of our plots were in stable stands. For analysis we used the

221 additional criterion of $<100$ conifer seedlings or saplings per hectare, resulting in $64 \%$ stable.

222 There was no relationship between plot type (healthy/sick) and seral type (chi-squared test for

223 equality of proportions, $\mathrm{p}=1$ ).

224 However, stable stands had lower sucker density than seral stands. Because sucker density was 225 substantially non-normal, we conducted a Wilcoxon test and found that 2013 sucker density was 226 systematically lower in stable plots (median=800 stems $\left.\mathrm{ha}^{-1}\right)$ than in seral plots $\left(1850 \mathrm{stems} \mathrm{ha}^{-1}\right.$, $227 \mathrm{p}=0.001)$. 
228 Browsing had no apparent relation to SAD occurrence. Browsing of regeneration was noted in

$22920 \%$ of plots and noted as heavy in $7 \%$ of plots. The proportion of plots browsed did not differ

230 significantly between healthy and sick plots (chi-squared test for equality of proportions, $\mathrm{p}=0.5$ ).

231 In the multiple regression analyses of the nine change variables, site and stand factors were

232 generally insignificant. However, change in live basal area was significantly influenced by both

233 plot type and stand structure $(\mathrm{p}<0.001$ and $\mathrm{p}=0.009$, respectively). In this case, live basal area

234 did not change significantly in two-story and multi-story stands, but single-story stands lost an

235 average of $5.1 \mathrm{~m}^{2} \mathrm{ha}^{-1}$ in live basal area after removing the effect of plot type. There was no

236 significant interaction between plot type and stand structure.

237 Change in live density over time was significantly influenced by elevation $(\mathrm{p}=0.015)$ and stand

238 structure $(\mathrm{p}=0.027)$. Elevation had a positive effect of one additional stem per hectare for every

239 four meters increase in elevation. Consistent with the effect of stand structure on live basal area,

240 single-story stands had about 163 fewer stems ha ${ }^{-1}$ than did two- and multi-story stands after

241 removing the effect of elevation.

\section{Discussion}

243 Because the SAD epidemic peaked in 2008 and was virtually over by 2009 , a decrease in recent

244 damage was expected for sick plots. Also, due to older damage, fewer trees were available in

245 sick plots to show damage. Indeed, some measures of recent damage decreased in sick plots,

246 including basal area of recently dead trees and to a lesser extent recent crown loss.

247 However, sick plots lost $28 \%$ of their live basal area since the first measurement. Moreover,

248 they continued to experience much higher levels of recent deterioration than healthy plots. Even

249 in 2013, sick plots still had almost three times as much recently dead basal area and over twice 
250 the density of recently dead trees compared to healthy plots. Recent crown loss was almost four

251 times higher in sick than in healthy plots. These measures of recent damage are estimated to

252 have occurred over the previous 2-3 years. This indicates that current damage in sick plots,

253 although not as severe as it was during the peak of the SAD episode, is still substantial. The

254 significant decrease in live basal area and increase in snag basal area in sick plots are evidence of

255 the cumulative impact of the ongoing damage. Considering that sick plots have well below half

256 the live density and basal area of healthy plots, but are losing stems, basal area and canopy 2-4

257 times faster, such stands are clearly continuing to deteriorate.

258 Healthy plots were stable and significantly increased in suckering (small regeneration),

259 especially among the healthiest plots. However, change in sucker density over time was

260 significantly different between healthy and sick plots. While sucker density increased

261 significantly in healthy plots, it trended in the opposite direction in sick plots, even as the

262 overstory continued to deteriorate.

263 Why have SAD-affected stands continued to deteriorate, long after drought conditions abated?

264 There may be several reasons. First, several of the secondary agents that were heavily involved 265 in SAD are capable of attacking and killing otherwise healthy trees when their populations are

266 high (Marchetti et al. 2011). Most important in this regard are the aspen bark beetle, bronze

267 poplar borer, and Cytospora canker. The large populations that grew through 2008 thus

268 continued to kill trees for some time after the inciting agent, drought, was no longer directly

269 involved. This conclusion is supported by the fact that these agents remained significantly more

270 frequent in sick plots than in healthy plots, often at three times the frequency. 
271 Second, heavy root mortality experienced during the SAD epidemic (Worrall et al. 2010) means

272 fewer roots to produce suckers and less water and nutrient absorption. Thus, stress on surviving

273 trees may be prolonged.

274 A third important factor is the positive feedback of overstory deterioration. Once aspen stands

275 begin to open up substantially, the forest floor is exposed to sun and wind, and the rest of the

276 stand can deteriorate rapidly (Fralish 1975; Walters et al. 1982). Indeed, microclimate

277 measurements in stands affected by SAD showed higher air and soil temperatures and lower soil

278 moisture than in healthier stands, suggesting stress and increased susceptibility to secondary

279 insects and pathogens for residual trees (Korb et al. 2014). Such deterioration is complete within

280 3-6 years in some regions, but can be more protracted in the Rocky Mountains (Frey et al. 2004).

281 Aspen stands not obviously impacted by SAD in a portion of our study area experienced

282 significant decreases in both density (stems $>1.37 \mathrm{~m}$ tall) and basal area over a longer sampling

283 interval (Coop et al. 2014). The authors concluded that this may represent the expected

284 dynamics of stand maturation, but also subtle influences of drought. A similar decrease in live

285 density was observed in our healthy plots along with increased density of recently dead trees, but

286 this was balanced with increased regeneration.

287 When we classified stands by conifer presence as stable or seral, several unexpected results were

288 found. One might hypothesize that seral stands are more likely to suffer from SAD, and indeed

289 conifer presence was associated with SAD in another area (Zegler et al. 2012). However,

290 relative conifer basal area was inversely related to elevation in that system, so the effect of

291 elevation may have been confounded with conifer presence. Our plots had a weak but opposite

292 pattern of conifer presence vs. elevation. Our data showed that the proportion of sick plots was 
293 equal among stable vs. seral plots. Similarly, one might expect stable stands to regenerate better 294 than seral stands, but quite the opposite was true. Stable stands had much lower 2013 sucker 295 density, although the proportion of SAD-affected stands was the same as in seral stands. Further 296 study is needed to better understand differences in regeneration potential between stable and 297 seral stands.

298 This study was not designed to assess the role of ungulate browsing in regeneration following 299 SAD. Browsing was not a significant factor influencing the change in regeneration between 300 measurements, and the proportion of browsed plots did not differ between healthy and sick plots.

301 However, some browsing may have gone undetected, especially when small suckers were 302 completely consumed. In many areas, browsing can be a major influence on aspen regeneration 303 (e.g., Binkley et al. 2006; Ohms 2003; Zegler et al. 2012).

304 Climate change will have substantial, negative impacts on aspen in much of its current range 305 (Rehfeldt et al. 2009; Worrall et al. 2013). A recent study concluded that, by the 2030's, 306 moisture conditions during the turn-of-the-century drought " . . . will become the new norm in 307 western North America. Towards the latter half of the twenty-first century the precipitation 308 regime associated with the turn of the century drought will represent an outlier of extreme 309 wetness" (Schwalm et al. 2012, pp. 552-553). It has also been suggested that there may be 310 indirect, positive impacts of climate change due to increased disturbance creating regeneration 311 opportunities for aspen (Kulakowski et al. 2013; Worrall et al. 2013). These are not contrary 312 views. Indeed, assuming climate is at least minimally suitable for aspen (which is unlikely to 313 remain true throughout the current distribution of aspen), disturbance is the key to (a) aspen

314 recovery where it is deteriorating following SAD, as reported here; (b) increasing drought 315 resilience; and (c) preparing seedbeds for aspen in newly suitable areas. Where disturbances 
316 occur naturally, they will counter the negative effects of climate change on aspen to some extent.

317 Where they do not, forest management can create those opportunities for aspen.

\section{Management implications}

319 On average, the overstories in affected stands are continuing to deteriorate and regeneration is

320 decreasing. Especially where ungulate browsing of suckers is common, the current trajectory

321 would suggest that such stands are unlikely to recover as the aspen stands that they were.

322 Without intervention, substantial areas of aspen forest may be lost.

323 Two studies indicate that aspen stands affected by SAD can be regenerated effectively, if

324 treatment is done before about $50 \%$ of the stand is lost. Both studies involved cutting, but fire 325 would probably be as effective. In southwestern Utah, coppice harvest was conducted in stands

326 with varying levels of mortality (Ohms 2003). In stands with 10-50\% mortality, post-harvest

327 regeneration ranged from about 10,000 to 100,000 stems $^{-1}$, but above $50 \%$ mortality it

328 dropped to near 0. Similarly, the regeneration response of SAD-affected stands was tested in the

329 Terror Creek watershed of southwestern Colorado (Shepperd et al. 2015). Mean sucker density

330 in uncut stands was higher in their study area (3865 stems ha $\left.{ }^{-1}\right)$ than in our survey (2069 stems

$331 \mathrm{ha}^{-1}$ ). Regeneration response was excellent, ranging from about 14,000 stems $^{-1}$ in treatments

332 that had $>60 \%$ pretreatment basal area dead or declining, to 55,000 stems ha $^{-1}$ in stands that had

$3330-20 \%$ dead or declining basal area. Sucker density was strongly associated with SAD severity

334 and pre-harvest live basal area.

335 These studies show that management intervention is likely to have good outcomes if not delayed

336 too long. Our results indicate that such management may be needed to facilitate recovery in

337 many aspen stands affected by SAD. 
338 In addition, the fact that most basal area was lost in single-story stands suggests that creating

339 multi-story stands, where feasible, may improve resilience. This is consistent with greater

340 resilience of young stands $<40 \mathrm{yr}$ old (Worrall et al. 2013).

\section{Acknowledgements}

342 We thank Ethan Bucholz, Kristin Barker, and Susan Bresney for excellent field work and data 343 management, and Roy Mask for procuring the funds to enable this study. Wayne Shepperd

344 kindly reviewed the manuscript before submission.

\section{$\underline{\text { Literature cited }}$}

345 Allen, C.D., Macalady, A.K., Chenchouni, H., Bachelet, D., McDowell, N., Vennetier, M.,

346 Kitzberger, T., Rigling, A., Breshears, D.D., Hogg, E.H., Gonzalez, P., Fensham, R., Zhang, Z.,

347 Castro, J., Demidova, N., Lim, J.-H., Allard, G., Running, S.W., Semerci, A., and Cobb, N.

348 2010. A global overview of drought and heat-induced tree mortality reveals emerging climate

349 change risks for forests. Forest Ecology and Management 259(4): 660-684.

350 Binkley, D., Moore, M.M., Romme, W.H., and Brown, P.M. 2006. Was Aldo Leopold right

351 about the Kaibab deer herd? Ecosystems 9(2): 227-241. doi:10.1007/s10021-005-0100-z.

352 Coop, J.D., Barker, K.J., Knight, A.D., and Pecharich, J.S. 2014. Aspen (Populus tremuloides)

353 stand dynamics and understory plant community changes over 46 years near Crested Butte,

354 Colorado, USA. Forest Ecology and Management 318: 1-12. doi:10.1016/j.foreco.2014.01.019.

355 Flack, J.A.D. 1976. Bird populations of aspen forests in western North America. Ornithological

356 Monographs 19: iii-viii, 1-97.

357 Fralish, J.S. 1975. Ecological and historical aspects of aspen succession in northern Wisconsin.

358 Transactions of the Wisconsin Academy of Sciences, Arts and Letters 63: 54-65. 
359 Frey, B.R., Lieffers, V.J., Hogg, E.H.T., and Landhäusser, S.M. 2004. Predicting landscape

360 patterns of aspen dieback: mechanisms and knowledge gaps. Canadian Journal of Forest

361 Research 34(7): 1379-1390. doi:10.1139/x04-062.

362 Gilbertson, R.L. 1980. Wood-rotting fungi of North America. Mycologia 72(1): 1-49.

363 Korb, J.E., Bombaci, S., and Siegel, R. 2014. The effect of sudden aspen decline on understory

364 microclimate and vegetation in southwestern Colorado. Canadian Journal of Forest Research

365 44(8): 914-921. doi:10.1139/cjfr-2014-0087.

366 Kuhn, T.J., Safford, H.D., Jones, B.E., and Tate, K.W. 2011. Aspen (Populus tremuloides)

367 stands and their contribution to plant diversity in a semiarid coniferous landscape. Plant Ecology

368 212(9): 1451-1463. doi:10.1007/s11258-011-9920-4.

369 Kulakowski, D., Matthews, C., Jarvis, D., and Veblen, T.T. 2013. Compounded disturbances in

370 sub-alpine forests in western Colorado favour future dominance by quaking aspen (Populus

371 tremuloides). Journal of Vegetation Science 24(1): 168-176. doi:10.1111/j.1654-

372 1103.2012.01437.x.

373 LaMalfa, E., and Ryel, R. 2008. Differential snowpack accumulation and water dynamics in

374 aspen and conifer communities: Implications for water yield and ecosystem function.

375 Ecosystems 11(4): 569-581. doi:10.1007/s10021-008-9143-2.

376 Manion, P.D. 1991. Tree Disease Concepts. second ed. Prentice-Hall, Englewood Cliffs, New

377 Jersey.

378 Manion, P.D., and LaChance, D. (eds). 1992. Forest Decline Concepts. APS Press, St. Paul, 379 Minnesota. 
380 Marchetti, S.B., Worrall, J.J., and Eager, T. 2011. Secondary insects and diseases contribute to 381 sudden aspen decline in southwestern Colorado, USA. Canadian Journal of Forest Research 382 41(12): 2315-2325. doi:10.1139/X11-106.

383 Michaelian, M., Hogg, E.H., Hall, R.J., and Arsenault, E. 2011. Massive mortality of aspen 384 following severe drought along the southern edge of the Canadian boreal forest. Global Change 385 Biology 17(6): 2084-2094. doi:10.1111/j.1365-2486.2010.02357.x.

386 Mueggler, W.F. 1985. Vegetation associations. In Aspen: ecology and management in the 387 western United States. General Technical Report RM-119. Edited by N.V. DeByle and R.P. 388 Winokur. Rocky Mountain Forest and Range Experiment Station, USDA Forest Service, Fort 389 Collins, Colorado. pp. 45-55.

390 Oaten, D.K., and Larsen, K.W. 2008. Aspen stands as small mammal "hotspots" within dry 391 forest ecosystems of British Columbia. Northwest Science 82(4): 276-285.

392 Ohms, S.R. 2003. Restoration of aspen in different stages of mortality in southern Utah. In 393 Range Science. Utah State University, Logan, Utah, USA. p. 99.

394 R Core Team. 2014. R: A language and environment for statistical computing. R Foundation for 395 Statistical Computing, Vienna, Austria.

396 Rehfeldt, G.E., Ferguson, D.E., and Crookston, N.L. 2009. Aspen, climate, and sudden decline in 397 western USA. Forest Ecology and Management 258(11): 2353-2364.

398 doi:10.1016/j.foreco.2009.06.005.

399 Rogers, P.C., Landhäusser, S.M., Pinno, B.D., and Ryel, R.J. 2014. A functional framework for 400 improved management of western North American aspen (Populus tremuloides Michx.). Forest 401 Science 60(2): 345-359. doi:10.5849/forsci.12-156. 
402 Schwalm, C.R., Williams, C.A., Schaefer, K., Baldocchi, D., Black, T.A., Goldstein, A.H., Law, 403 B.E., Oechel, W.C., Paw U, K.T., and Scott, R.L. 2012. Reduction in carbon uptake during turn 404 of the century drought in western North America. Nature Geoscience 5(8): 551-556.

405 doi:10.1038/ngeo1529.

406 Shepperd, W.D., Smith, F.W., and Pelz, K. 2015. Group clearfell harvest can promote

407 regeneration of aspen forests affected by sudden aspen decline in western Colorado. Forest

408 Science 61. doi:10.5849/forsci.14-101.

409 Turchi, G.M., Kennedy, P.L., Urban, D., and Hein, D. 1995. Bird species richness in relation to 410 isolation of aspen habitats. The Wilson Bulletin 107(3): 463-474.

411 van Mantgem, P.J., Stephenson, N.L., Byrne, J.C., Daniels, L.D., Franklin, J.F., Fule, P.Z.,

412 Harmon, M.E., Larson, A.J., Smith, J.M., Taylor, A.H., and Veblen, T.T. 2009. Widespread

413 increase of tree mortality rates in the western United States. Science 323(5913): 521-524.

414 doi:10.1126/science.1165000.

415 Venables, W.N., and Ripley, B.D. 2002. Modern Applied Statistics with S. Fourth ed. Springer, 416 New York.

417 Walters, J.W., Hinds, T.E., Johnson, D.W., and Beatty, J.S. 1982. Effects of partial cutting on 418 diseases, mortality and regeneration of Rocky Mountain aspen stands. Rocky Mountain Forest 419 and Range Experiment Station, USDA Forest Service. Research Paper. RM-240.

420 Worrall, J.J., Egeland, L., Eager, T., Mask, R.A., Johnson, E.W., Kemp, P.A., and Shepperd, 421 W.D. 2008. Rapid mortality of Populus tremuloides in southwestern Colorado, USA. Forest

422 Ecology and Management 255(3-4): 686-696. doi:10.1016/j.foreco.2007.09.071. 
423 Worrall, J.J., Marchetti, S.B., Egeland, L., Mask, R.A., Eager, T., and Howell, B. 2010. Effects

424 and etiology of sudden aspen decline in southwestern Colorado, USA. Forest Ecology and

425 Management 260(5): 638-648. doi:10.1016/j.foreco.2010.05.020.

426 Worrall, J.J., Rehfeldt, G.E., Hamann, A., Hogg, E.H., Michaelian, M., Marchetti, S.B., and

427 Gray, L.K. 2013. Recent declines of Populus tremuloides in North America linked to climate.

428 Forest Ecology and Management 299: 35-51. doi:10.1016/j.foreco.2012.12.033.

429 Zegler, T.J., Moore, M.M., Fairweather, M.L., Ireland, K.B., and Fulé, P.Z. 2012. Populus

430 tremuloides mortality near the southwestern edge of its range. Forest Ecology and Management

431 282: 196-207. doi:10.1016/j.foreco.2012.07.004.

432 
Table 1. Percentage of live and recently dead aspen stems with insects and biotic diseases. The first three were the most important contributing agents in SAD (Marchetti et al. 2011).

\begin{tabular}{|c|c|c|c|c|}
\hline \multirow[b]{2}{*}{ Insect or disease } & \multirow[b]{2}{*}{ Plot type } & \multicolumn{2}{|c|}{ Percent of stems } & \multirow[b]{2}{*}{2007 vs. $2013^{a}$} \\
\hline & & 2007 & 2013 & \\
\hline \multirow[t]{3}{*}{ Aspen bark beetle } & Healthy & 4.3 & 5.4 & $\mathrm{p}=0.264$ \\
\hline & Sick & 30.5 & 25.8 & $\mathrm{p}=0.051$ \\
\hline & Healthy vs. sick ${ }^{a}$ & & $\mathrm{p}<0.001$ & \\
\hline \multirow[t]{3}{*}{ Bronze poplar borer } & Healthy & 6.2 & 11.5 & $\mathrm{p}<0.001$ \\
\hline & Sick & 41.6 & 31.4 & $\mathrm{p}<0.001$ \\
\hline & Healthy vs. sick & & $\mathrm{p}<0.001$ & \\
\hline \multirow[t]{3}{*}{ Cytospora canker } & Healthy & 12.6 & 13.2 & $p=0.753$ \\
\hline & Sick & 46.0 & 34.1 & $\mathrm{p}<0.001$ \\
\hline & Healthy vs. sick & & $\mathrm{p}<0.001$ & \\
\hline \multirow[t]{3}{*}{ Poplar borer } & Healthy & 10.5 & 17.1 & $\mathrm{p}<0.001$ \\
\hline & Sick & 21.8 & 29.0 & $\mathrm{p}=0.002$ \\
\hline & Healthy vs. sick & & $\mathrm{p}<0.001$ & \\
\hline \multirow[t]{3}{*}{ White trunk rot } & Healthy & 19.2 & 20.8 & $\mathrm{p}=0.395$ \\
\hline & Sick & 21.8 & 18.3 & $\mathrm{p}=0.101$ \\
\hline & Healthy vs. sick & & $\mathrm{p}=0.256$ & \\
\hline \multirow[t]{3}{*}{ Sooty-bark canker } & Healthy & 0.5 & 1.8 & $\mathrm{p}=0.008$ \\
\hline & Sick & 5.5 & 3.7 & $\mathrm{p}=0.124$ \\
\hline & Healthy vs. sick & & $\mathrm{p}=0.028$ & \\
\hline
\end{tabular}


${ }^{a}$ Equality of proportions infested was assessed with a chi-squared test for equal distribution. Proportions were based on 1186 and 1021 trees inspected in healthy and sick plots in 2007/08, and 1016 and 601 trees in 2013, respectively. 
Figures

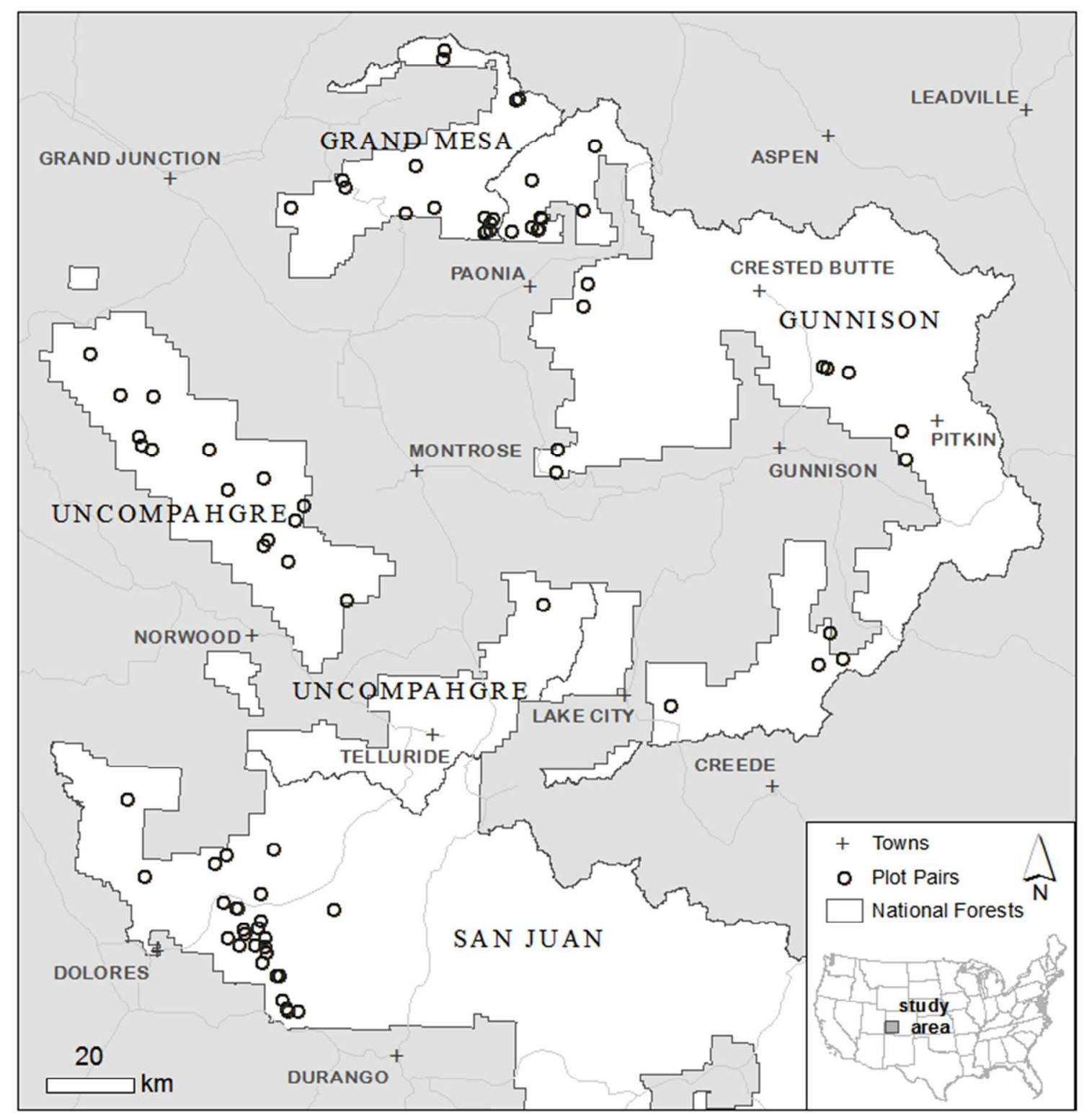

Figure 1. Locations of plot pairs (healthy and sick) in southwestern Colorado. 


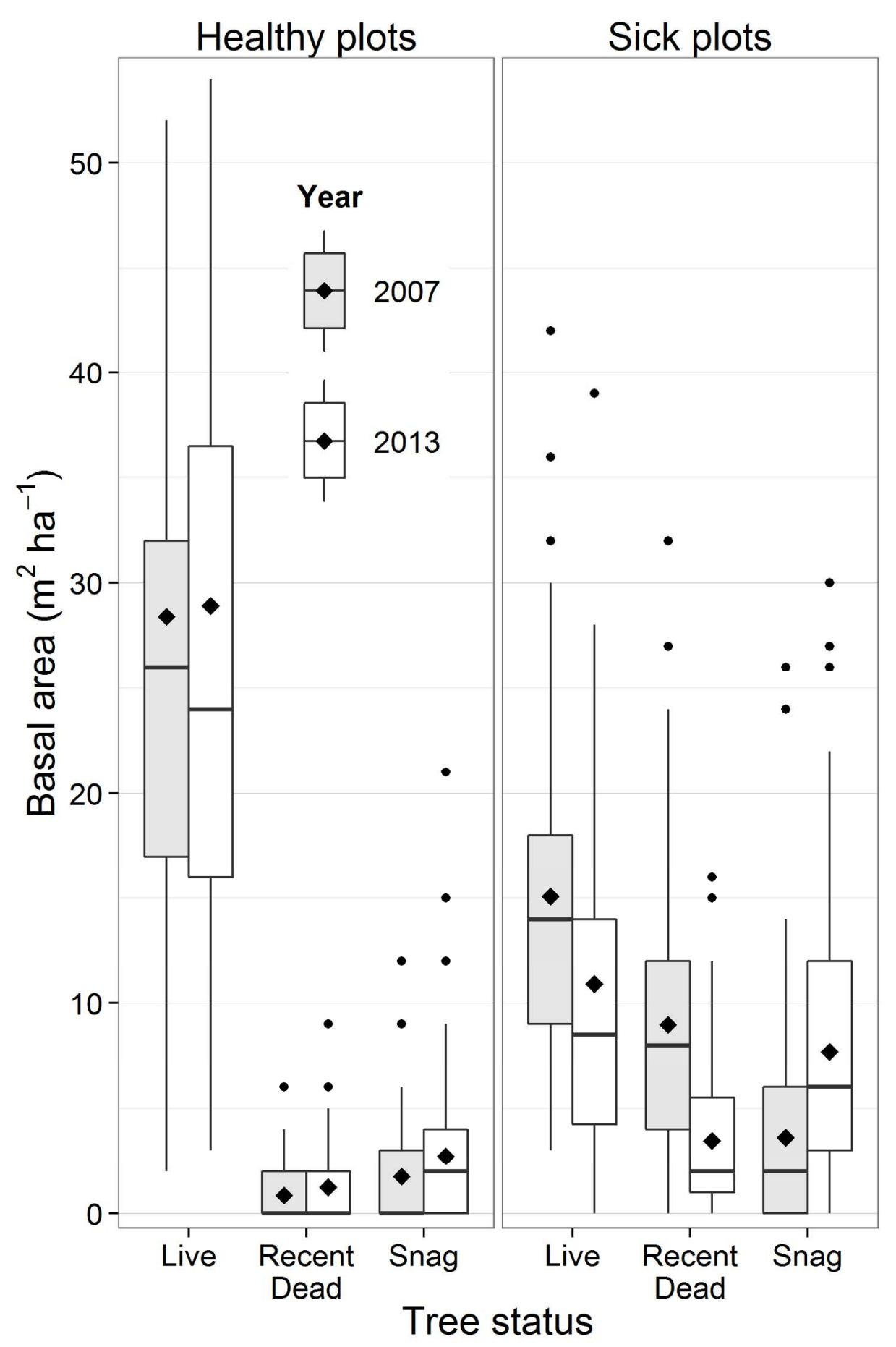

Figure 2. Basal area of live, recently dead and long-dead (snag) standing trees in healthy and sick plots in 2007/08 and 2013. The lower and upper box edges are the first and third quartile (containing the middle $50 \%$ of values), the bold horizontal line is the second quartile (median), the whiskers extend to the farthest points within 1.5 times the range of the box, the dots are outliers, and the solid diamond is the mean. To show detail in the lower end of the scale, two healthy plots with outliers of live basal area are not shown: 90 and $102 \mathrm{~m}^{2} \mathrm{ha}^{-1}$ in 2007 and $93 \mathrm{~m}^{2}$ $\mathrm{ha}^{-1}$ each in 2013. 


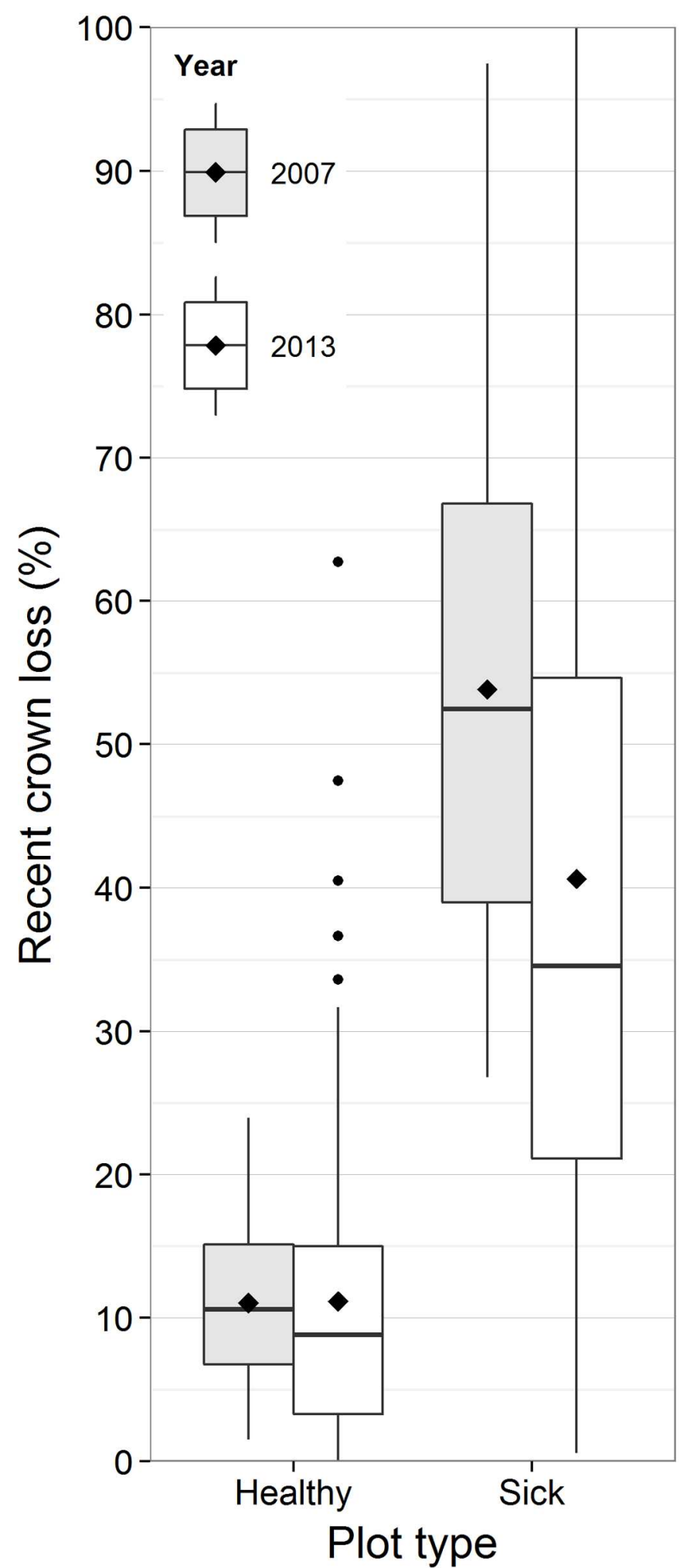

Figure 3. Recent crown loss in healthy and sick plots as measured in 2007/08 and 2013. Symbology is as described for Fig. 2. Recent crown loss is based on twig and branch condition and is estimated to have occurred within the preceding 2-3 years. 


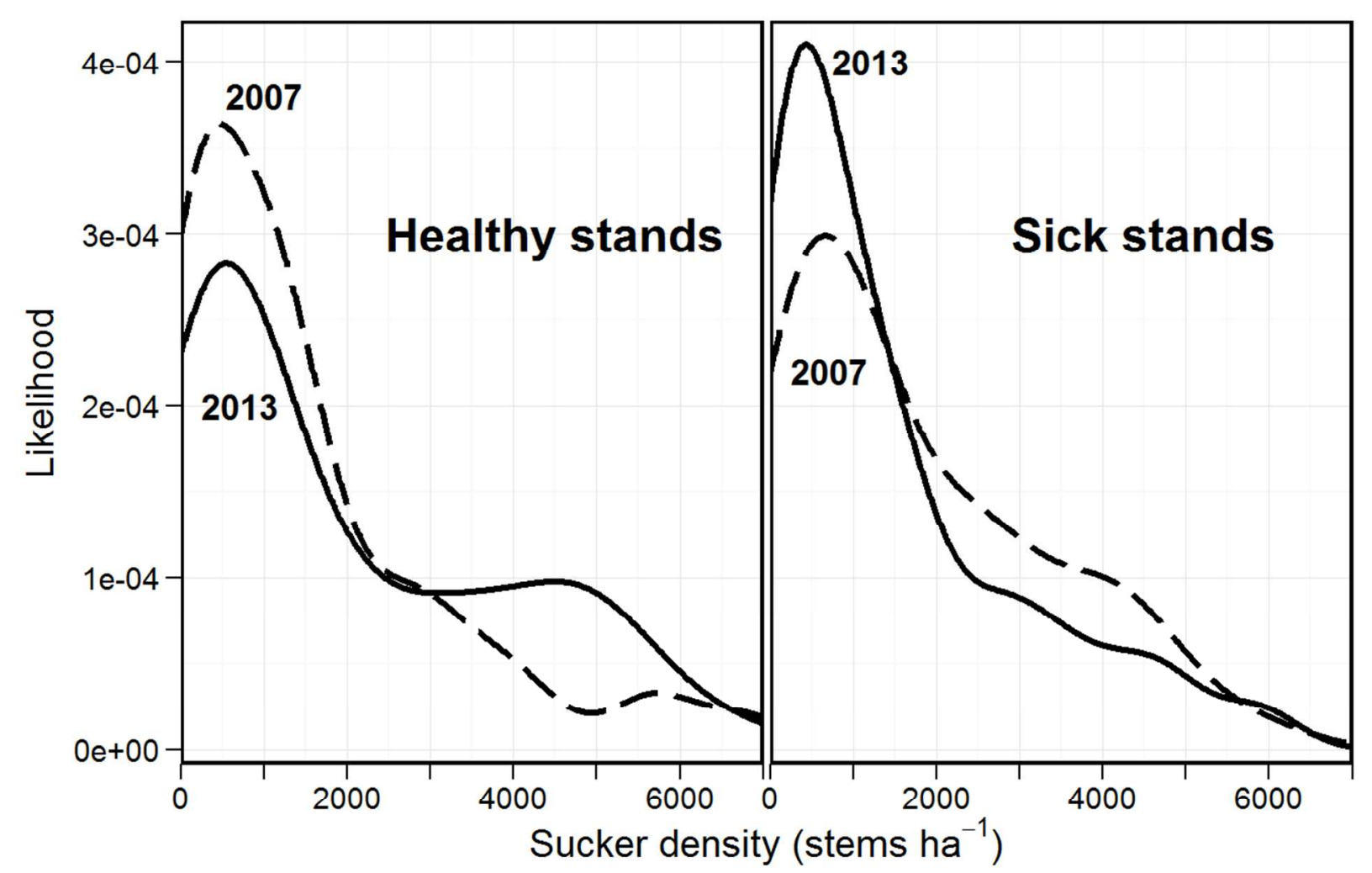

Figure 4. Estimated frequency distribution of sucker density among healthy and sick aspen stands in 2007/08 vs. 2013, based on repeated measurement of 159 plots. Likelihood is a smoothed representation of a histogram; its value is proportional to the likelihood of the corresponding sucker density in the sampled population. 